\title{
Prevalence, Risk Factors and Awareness about HCV Infection in Pregnant Women in a Tertiary Care Center in North India
}

\author{
By Dr. Renu Gupta, Dr. Rashmi Kumari, Dr. Shaily Agarwal, \\ Dr. Kiran Pandey, Dr. Neena Gupta \& Dr. Pavika Lal
}

Introduction- Among the viral infections affecting the liver in pregnancy, Hepatitis C though uncommon now is recognized to be a serious global public health problem affecting 170 million people worldwide I .e. 3\% of the population [1]. The prevalence of anti-HCV antibody in pregnant women in developed countries ranges from 0.14 to $4.4 \%$, whereas the seroprevalence in Indian pregnant female population is $1.03 \%[2,3,4]$.

Following the decreasing transmission of HCV by blood -transfusion, intravenous drug use has now become the primary route of new HCV infections in adults while mother to child transmission (MTCT) is the major route of new infections in young children in the developed as well as in developing countries.[5] Approximately $7-8 \%$ of hepatitis C virus-positive women transmit this virus to their offspring [6] mainly because they are ignorant about this infection and unaware of their status. The natural course of hepatitis $\mathrm{C}$ is a progression from acute hepatitis to chronic hepatitis, which occurs in 55\%- $85 \%$ of patients.

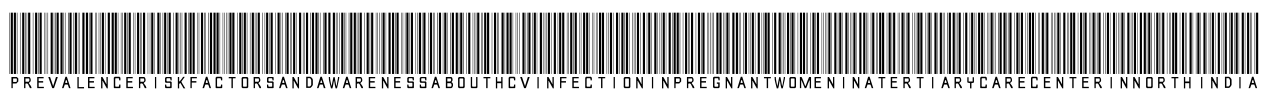

Strictly as per the compliance and regulations of:

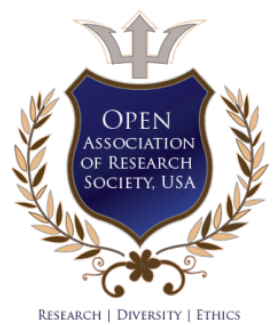

(C) 2020. Dr. Renu Gupta, Dr. Rashmi Kumari, Dr. Shaily Agarwal, Dr. Kiran Pandey, Dr. Neena Gupta \& Dr. Pavika Lal. This is a research/review paper, distributed under the terms of the Creative Commons Attribution-Noncommercial 3.0 Unported License http://creativecommons.org/licenses/by-nc/3.0/), permitting all non-commercial use, distribution, and reproduction in any medium, provided the original work is properly cited. 


\title{
Prevalence, Risk Factors and Awareness about HCV Infection in Pregnant Women in a Tertiary Care Center in North India
}

\author{
Dr. Renu Gupta ${ }^{\alpha}$, Dr. Rashmi Kumari ${ }^{\sigma}$, Dr. Shaily Agarwal ${ }^{\rho}$, Dr. Kiran Pandey ${ }^{\omega}$, \\ Dr. Neena Gupta ${ }^{*} \&$ Dr. Pavika Lal ${ }^{\S}$
}

\section{INTRODUCTION}

A mong the viral infections affecting the liver in pregnancy, Hepatitis $C$ though uncommon now is recognized to be a serious global public health problem affecting 170 million people worldwide I .e. $3 \%$ of the population [1]. The prevalence of anti-HCV antibody in pregnant women in developed countries ranges from 0.14 to $4.4 \%$, whereas the seroprevalence in Indian pregnant female population is $1.03 \%[2,3,4]$.

Following the decreasing transmission of $\mathrm{HCV}$ by blood -transfusion, intravenous drug use has now become the primary route of new HCV infections in adults while mother to child transmission (MTCT) is the major route of new infections in young children in the developed as well as in developing countries.[5] Approximately $7-8 \%$ of hepatitis $C$ virus-positive women transmit this virus to their offspring [6] mainly because they are ignorant about this infection and unaware of their status. The natural course of hepatitis $C$ is a progression from acute hepatitis to chronic hepatitis, which occurs in 55\%- $85 \%$ of patients.

Hepatitis C infection leads to chronic liver disease, cirrhosis as well as known to cause hepatocellular carcinoma. Still World Health Organization (WHO) do not recommend the universal screening of Hepatitis B and C in pregnant women, although testing of HIV is mandatory after proper voluntary counseling. The study was undertaken with the aim to assess the exclusive seroprevalence of Hepatitis $\mathrm{C}$ infection in pregnant females and to know the risk factors, their attitude, and awareness against this dreadful disease.

Author a: Associate Professor, Department of obstetrics and gynaecology GSVM Medical College Kanpur.

Author 6: JR3, Department of obstetrics and gynaecology GSVM Medical College Kanpur.

Author p: Associate Professor, Department of obstetrics and gynaecology GSVM Medical College Kanpur.

Author w: Professor and Head of Department, Department of obstetrics and gynaecology GSVM Medical College Kanpur.

Author $¥$ : Professor, Department of obstetrics and gynaecology GSVM Medical College Kanpur.

Corresponding Author \$: Assistant professor, Department of obstetrics and gynaecology GSVM Medical College Kanpur.

e-mail: lalpavika@gmail.com

\section{il. Material and Methods}

This was a prospective observational study done at our tertiary care center in the obstetrics and gynecology department of UISEMH,GSVM Medical College in Kanpur(India) from November 2017 to August 2019.After taking a proper written informed consent, all antenatal women attending the OPD and in emergency who were exclusively HCV positive were included in the study group. Age, Parity, Gestational age-matched women delivering during the same time frame who were tested negative for HCV were taken as controls. The initially reactive samples were re-tested and considered ELISA positive if both results were reactive. Once hepatitis $\mathrm{C}$ was diagnosed, a qualitative HCV RNA test was done to determine the baseline viral load by RNA PCR. A structured questionnaire was prepared comprising of questions and a face to face interview was done to know the awareness of viral infections during the antenatal period.

Those previously diagnosed to have some chronic liver disease, Intrahepatic cholestasis of pregnancy, or co-infection with HIV and Hepatitis B were excluded from the study. Laboratory tests to evaluate the extent of liver disease were done, including the following: Bilirubin, ALT, AST, albumin, platelet count, and prothrombin time. A total of 5853 antenatal patients had reported during the study period, out of which 126 were found to be HCV positive. The patients were further advised for HCV RNA, but only 98 had opted for HCV RNA.

Statistical Analysis- Data was analyzed using SPSS 22.0.Categorical variables were analyzed using the Odds ratio (OD), and the Chi-square test \& p-value $<0.05$ were considered significant. The study has been approved by the Ethics Committee of GSVM Medical College, Kanpur.

\section{Results}

One hundred twenty-six $(2.15 \%)$ of the 5853 pregnant women tested positive for anti HCV antibodies. Of these, 72 (73.4\%) were positive for HCV RNA by RT PCR. Most of the HCV reactive obstetric patients were in the reproductive age group and the mean age was 26.3 
years. Slightly higher rate of infection was found among women living in rural areas, which was $58.7 \%$ while that in the urban area was $41.2 \%$.Both study and control groups had similar educational qualifications. (Table 1)

Most patients in the study group belonged to lower socioeconomic status. In the HCV infected group, $44.4 \%$ patients belonged to lower socioeconomic status, while only $26.9 \%$ were of upper socioeconomic status. $46.8 \%$ were diagnosed in the intrapartum period, while only $38 \%$ were diagnosed during their antenatal visits among the risk factors for HCV infection previous history of blood transfusions, dilatation and curettage, previous surgery were studied as independent risk factors (Table 2). The majority, $52.7 \%$ of the RNA positive patients and $46.1 \%$ in RNA negative had a history of any surgery (Table 3). Of the $126 \mathrm{HCV}$ positive patients, $22 \%$ did not have any identifiable risk factors. Of the 5853 patients questioned, maximum awareness was about HIV and least about HCV (Table 4).

Table 1: Demographic Distribution In Hcv Positive Obstetric Patients

\begin{tabular}{|c|c|c|}
\hline & \multicolumn{2}{|c|}{ HCV POSITIVE(N=126) } \\
\cline { 2 - 3 } & NUMBER & PERCENTAGE \\
\hline TOTAL & 126 & $\%$ \\
\hline AGE & 41 & 32.5 \\
15-24 year & 80 & 63.5 \\
$25-35$ & 05 & 3.9 \\
35 & 74 & 58.7 \\
HABITAT & 52 & 41.2 \\
Rural & & 21.4 \\
Urban & 27 & 78.5 \\
PARITY & 99 & 40.4 \\
Nullipara & & 46.0 \\
Multipara & 51 & 13.49 \\
EDUCATION STATUS & 58 & \\
Illiterate & 17 & \\
Primary & & \\
Secondary & & \\
\hline
\end{tabular}

Table 2: Association of Risk Factors in HCV Positive Obstetric Patients

\begin{tabular}{|c|c|c|c|c|}
\hline \multirow{2}{*}{ Risk Factors } & \multicolumn{2}{|c|}{$\begin{array}{l}\text { HCV Positive } \\
\quad(n=126)\end{array}$} & \multirow{2}{*}{$\begin{array}{l}\text { HCV Negative } \\
\quad(n=5727)\end{array}$} & \multirow{2}{*}{$\mathrm{p}$-value } \\
\hline & $\begin{array}{l}\text { HCV RNA Positive } \\
(\mathrm{n}=72)\end{array}$ & $\begin{array}{c}\text { HCV RNA } \\
\text { negative }(n=26)\end{array}$ & & \\
\hline \multirow[t]{2}{*}{$\mathrm{H} / \mathrm{O}$ Blood transfusion } & 16 & 9 & 456 & \multirow[t]{2}{*}{$<0.001^{\star}$} \\
\hline & $32 \%$ & $40.9 \%$ & $8.0 \%$ & \\
\hline \multirow[t]{2}{*}{$\mathrm{H} / \mathrm{O}$ Abortions } & 04 & 03 & 1125 & \multirow[t]{2}{*}{$<0.001^{\star}$} \\
\hline & $8 \%$ & $13.6 \%$ & $19.6 \%$ & \\
\hline \multirow[t]{2}{*}{$\mathrm{H} / \mathrm{O}$ multiple sex partners } & 03 & 02 & 25 & \multirow[t]{2}{*}{0.00001} \\
\hline & $4.1 \%$ & $7.6 \%$ & $0.43 \%$ & \\
\hline \multirow[t]{2}{*}{ H/O Episiotomy } & 24 & 12 & 3818 & \multirow[t]{2}{*}{$0.00001^{\star}$} \\
\hline & 33.3 & 46.1 & 66.6 & \\
\hline
\end{tabular}


Table 3: Association of Surgery as Risk Factor in HCV Positive Obstetric Patients

\begin{tabular}{|c|c|c|c|c|}
\hline \multirow[b]{2}{*}{ Risk factors } & \multicolumn{2}{|c|}{ HCV Positive } & \multirow[b]{2}{*}{$\begin{array}{l}\text { HCV Negative } \\
(n=5727)\end{array}$} & \multirow{2}{*}{$\begin{array}{c}\mathrm{p} \\
\text { value }\end{array}$} \\
\hline & $\begin{array}{c}\text { HCV RNA } \\
\text { positive } \\
(n=72)\end{array}$ & $\begin{array}{c}\text { HCV RNA } \\
\text { negative } \\
(n=26)\end{array}$ & & \\
\hline \multirow[t]{2}{*}{$\mathrm{H} / \mathrm{O} \mathrm{D} \& \mathrm{C}$} & 06 & 04 & 987 & \multirow[t]{2}{*}{$0.00603^{x}$} \\
\hline & $12 \%$ & $18.2 \%$ & $17.2 \%$ & \\
\hline \multirow{2}{*}{$\begin{array}{c}\mathrm{H} / \mathrm{O} \text { Previous } \\
\text { surgery }\end{array}$} & 15 & 7 & 1007 & \multirow[t]{2}{*}{$0.041^{*}$} \\
\hline & $30 \%$ & $31.8 \%$ & $17.6 \%$ & \\
\hline \multirow{2}{*}{$\begin{array}{l}\mathrm{H} / \mathrm{O} \text { Dental } \\
\text { procedure }\end{array}$} & 01 & 00 & 12 & \multirow[t]{2}{*}{0.168} \\
\hline & $1.38 \%$ & 00 & $0.2 \%$ & \\
\hline \multirow[t]{2}{*}{$\mathrm{H} / \mathrm{O}$ Amniocentesis } & 01 & 00 & 24 & \multirow[t]{2}{*}{0.523} \\
\hline & $0.79 \%$ & $1.38 \%$ & $0.41 \%$ & \\
\hline
\end{tabular}

Table 4: Awareness of Various Viral Infections in Pregnancy

\begin{tabular}{|l|c|c|c|c|c|c|c|}
\hline \multirow{2}{*}{} & \multicolumn{2}{|c|}{ HIV } & \multicolumn{2}{c|}{ HBsAg } & \multicolumn{2}{c|}{ HCV } \\
\cline { 3 - 8 } & No. & $\%$ & No. & $\%$ & No. & $\%$ \\
\hline $\begin{array}{l}\text { Do you know the } \\
\text { various routes of } \\
\text { transmission? }\end{array}$ & YES & 3506 & 59.9 & 1880 & 32.1 & 1006 & 17.1 \\
\cline { 2 - 8 } & NO & 2347 & 40 & 3973 & 67.8 & 4847 & 82.8 \\
\hline $\begin{array}{l}\text { Do you know about } \\
\text { mother to child } \\
\text { transmission? }\end{array}$ & YES & 1290 & 22.03 & 1205 & 20.5 & 985 & 16.8 \\
\cline { 2 - 8 } & NO & 4563 & 77.9 & 4648 & 79.4 & 4868 & 83.17 \\
\hline $\begin{array}{l}\text { Do you know Breast } \\
\text { feeding transmits this } \\
\text { infection? }\end{array}$ & YES & 2350 & 40.1 & 1810 & 30.9 & 1200 & 20.5 \\
\cline { 2 - 8 } & NO & 3503 & 59.8 & 4043 & 69.0 & 4653 & 79.4 \\
\hline
\end{tabular}

\section{Discussion}

Our study represents a single hospital-based report to define the seroprevalence, risk factors, and knowledge of hepatitis $\mathrm{C}$ infection in our patient population of pregnant women which usually caters to Kanpur and it's adjoining areas (Kanpur-Dehat).

The prevalence of Hepatitis C positive pregnant women was found to be $2.15 \%$ in our study, which is almost double the reported prevalence of $1.03 \%$ in a study from North India by Kumar A et al. [7] and similar to the findings of other epidemiologic studies $[3,11]$. Prevalence in western countries ranges from 0.14 to $4.4 \%$ due to more awareness towards one's health, education and better health care facilities [2, 3]. The highest prevalence of infection occurs among the individuals of the reproductive age group 25-35 years because this is the peak age group and also at the same time explains the increased chances of exposure of these group of women to risk factors. $[8,9,10]$.

The study also found a higher rate of infection among women living in rural areas, with higher parity and those belonging to rural areas. Higher infection rates among rural residents may be partially explained by the higher prevalence of anemia among rural women. Leiken et al. have reported a higher mean parity of HCV positive patients in their study [10]. They might be at increased risk because of their past pregnancies, hospital admissions, past surgeries, obstetrical procedures, and blood transfusions.

Earlier studies by Bohman VR et al. have found an association between the prevalence of HCV and the known risk factors of this infection [11]. In our study, history of $D \& C$, surgery, and blood transfusion were found to be major risk factors for transmission of $\mathrm{HCV}$ infection. Patients are exposed to unsterilized instrumentation where D\&C is done by paramedical staff without maintaining aseptic conditions. Also in a study by Hutin $Y$ et al., it has been reported that in resourcepoor countries, the risk of iatrogenic HCV infection is high [12]. Intravenous drug abuse is a significant risk factor in western countries [13]. In a study from Northern Italy, the principal risk factors were a history of intravenous drug abuse (32\%) and exposure to blood products (24\%).

It was found that $73.4 \%$ of the anti-HCV antibody-positive pregnant women had detectable HCV RNA in their blood, a figure that is similar to that found in most of the studies.[15-17]

We found no significant association with maternal and neonatal morbidity, but there are few studies which reveal increased risk of obstetric complications, but they had a few sample size, which 
was inconclusive. In our study there was no significant variation in the level of liver enzymes Serum transaminases and total bilirubin. This finding was similar to a study by Paternoster et al. [14] supporting the immune-mediated hypothesis.

In the present study, it was found that a substantial proportion of women with HCV had no evidence of exposure to any known risk factors in their history, about $22 \%$ of patients did not have any identifiable risk factor. This is comparable with the observation by Ward $C$ et al. [15], that $40-73 \%$ of the women had no obvious risk factors for HCV infection at the time of booking. It has been found that selective antenatal screening policy based on risk factors, failed to identify over half of infected patients. [18]

Routine antenatal HCV screening is not mandatory in India, but identification of HCV in pregnant women is important because of their risk of long term complications of infection, potential effects on pregnancy, and risk of transmission to their infants. Therefore universal screening for $\mathrm{HCV}$ can be recommended.

\section{Conclusion}

In our study, we found that there is high prevalence of Hepatitis $C$ infection in pregnant women posing a public health problem. Organizational bodies such as American College of Obstetricians and Gynecologists and Society for Maternal and Fetal medicine recommend selective antenatal screening solely based on high-risk factors which fail to identify over half of the infected patients, therefore universal screening in a pregnant female is justifiable and should be recommended to identify patients without any risk factors. Although it does not adversely affect the maternal or the neonatal outcome, but hepatitis $\mathrm{C}$ has long term ill effects on the health of both the mother and the child.

The need of the hour is to increase the awareness of hepatitis $\mathrm{C}$ infection by implementing educational programs through mass media as presently done for HIV infection as well as by emphasis on preventive measures such as sterilization of instruments, screening blood and blood products and making services more accessible with increasing utilization of antenatal services in rural areas.

\section{References Références Referencias}

1. Baldo V, Baldovin T, Trivello R, et al. Epidemiology of HCV infection. Curr Pharm Des. 2008; 14: 16461654. doi: 10.2174/138161208784746770.

2. Ward C, Tudor-Williams G, Cotzias $T$, et al. Prevalence of hepatitis $C$ among pregnant women attending an inner London obstetric department: uptake and acceptability of named antenatal testing. Gut. 2000; 47(2): 277-280. doi: 10.1136/gut.47.2.277.

3. Silverman NS, Jenkin BK, Wu C, et al. Hepatitis C virus in pregnancy: seroprevalence and risk factors for infection. Am J Obstet Gynecol. 1993; 169:583587. doi: 10.1016/0002-9378(93)90627-U.

4. Kumar A, Sharma KA, Gupta RK. Prevalence \& risk factors for hepatitis C virus among pregnant women. Indian J Med Res. 2007; 126:211-215.

5. Arshad M, El-Kamary SS, Jhaveri R. Hepatitis C virus infection during pregnancy and the newborn period - are they opportunities for treatment? Journal of viral hepatitis. 2011; 18:22936.

6. ACOG Educational Bulletin Viral hepatitis in pregnancy. Number 248, July 1998. American college of obstetricians and gynecologists. Int J Gynaecol Obstet. 1998; 63:195-202.

7. Kumar A, Sharma KA, Gupta RK. Prevalence \& risk factors for hepatitis C virus among pregnant women. Indian J Med Res. 2007; 126:211-215.

8. Centres for disease control and prevention, Recommendations for prevention and control of Hepatitis C virus (HCV) infection and HCV related disease. Morb Mortal Wkly Rep 1998;47:1-39

9. Wasley $A D$, AlterMJ, Epidemeology of Hepatitis C .Semin Liver Dis 2000;20;1-16

10. Leikin EL, Reinus JF, Schmell, Tejani N .Epidemeological predictors of hepatitis $\mathrm{C}$ virus infection in pregnant women. ObstetGynecol 1994;84;529-34

11. Bohman VR, StettlerW, LittleBB, WendelGD, SutorLJ, Cunningham FG, Seroprevalence and risk factors for hepatitis $C$ Virus in pregnant women. ObstetGynecol 1992:80:609-13

12. Hutin $Y$, HauriA, ArmstrongG. Use of injections in healthcare settings worldwide, 000: literature review and regional estimates. BMJ 2003;327:1073-8

13. Pergam SA, Wang CC, Gardella CM, et al. Pregnancy complications associated with hepatitis C: data from a 2003-2005 Washington state birth cohort. Am J Obstet Gynecol. 2008; 199(1):38.el38.e9.

14. Peternoster DM, Santarossa C, Grella P, et al. Viral load in HCV RNA-positive pregnant women. Am J Gastroentrol. 2001; 96(9):2751-2754.

15. Ward C, Tudor Williams G, CotziasT, Hargreaves S, Regan L, FosterGR. Prevalence of hepatitis C among pregnant women attending an inner London obstetric department: uptake and acceptability of named antenatal testing .Gut 2000;47:277-80

16. Saez A, LosaM, LolaconoO, LozanoC, AlvarezE, PitaL, etal. Diagnostic and prognostic value of virologic tests in vertical transmission of hepatitis $C$ virus infection: results of a large prospective study in 
pregnant women. Hepatogastroenterology 2004;51:1104-8

17. Conte D, FraquelliM, Prati D, Colucci A, Minola E. Prevalence and clinical course of chronic hepatitis $C$ virus infection and rate of HCV vertical transmission in a cohort of 15,250 pregnant women. Hepatology 2000;31:751-5

18. Jabeen T, CannonB, Hogan J et al. Pregnancy and pregnancy outcome in hepatitis $C$ type 1b.QJM .2000;93:597-601. 